\title{
DECISIONS REGARDING INVESTMENTS IN RENEWABLE ENERGY
}

\author{
Teodor Hada ${ }^{1}$ \\ Attila Tamas Szora ${ }^{2}$
}

\begin{abstract}
The article approaches issues regarding the decisions to invest in projects concerning the area of renewable energy resources. The decisions have been taken on the basis of the costbenefit analysis. The central issue, that arises inhere, concerns the foundation of the investment decision in terms of an EU funded project through structural funds, if the financial analysis indicators are sufficiently relevant for the decision, or when it should or should not resort to indicators of economic analysis for this, even for private investors, as if these projects should not be financed solely by public beneficiaries as infrastructure projects and not in the context of economic competitiveness, respectively.
\end{abstract}

Key words: renewable energy, cost-benefit analysis, IRR, NPV, investment decision

JEL codes: Q27, G21, E22, D63

\section{Introduction}

The general objective, drafted with the participation of this article's authors, is to produce energy from renewable resources by using the conversion of the solar energy into electricity through the development of a photovoltaic park area of 53.400 square meters with an installed power of 2,5 Mw, in the context of the superior capitalization of the local natural, material and human resources, of increased competitiveness and increased share of renewable energy producers, as well as consistent promotion of the horizontal priorities agreed upon by the EU member states, namely equal opportunities, environmental protection, energy efficiency and informational society. The specific objectives consist of:

- Reducing the dependency on imported energy resources within SEN (National Energetic System) and improving security of supply once the production begins in the first year with an output of $3800 \mathrm{Mwh}$

- Supporting Romania's strategy to reach a share of electricity produced from renewable resources out of the total gross consumption of electricity of $33 \%$ in $2010,35 \%$ in 2015 and $38 \%$ in 2020

- Protecting the environment by reducing the polluting CO2 emissions by 3.096.239,00 $\mathrm{kg} /$ year and fighting climatic change beginning with the first year of production

- The superior capitalization of the local resources (both human and natural) and of the local potential, mainly as a result of reintroducing within the economic circuit a brownfield land of 53.400 square meters

- Creating 8 jobs and reducing unemployment.

The segment, which the study is completed for, resides at the enterprise level, but we believe that its conclusions are valid for both industry and financing strategy of similar projects from EU funds.

In this research we aimed to identify key elements in determining the specific financial indicators from EU-funded projects in renewable energy. A critical documentary was performed upon a grant project developed with the participation of authors as upon different analysis, studies

\footnotetext{
${ }^{1}$ Professor PhD, “1 Decembrie 1918” University Alba Iulia, teohadauab@yahoo.com

2Assistant professor PhD “1 Decembrie 1918” University Alba Iulia, attaconsulting@yahoo.com
} 
and guidelines developed by the Managing Authorities in Romania for admission to financing of projects under EU programs, to complete the research, naturally taking regard of the basic orientation of the EU's Commission no. 4 Framework Document, in particular relating to the preparation of cost-benefit analysis of these projects.

The conclusion of our study is that the financing of renewable energy in Romania is not appropriate on the basis of financial indicators of investment, but it is appropriate based on economic indicators, and indirect benefits, respectively.

\section{Literature review}

The context and the starting point of this study is a rich specialized literature that defines the conceptual framework of the financial indicators of public or private investment projects; on the other hand, this literature sets the limits of this indicators in accordance to the economic context.

The macroeconomic context influences decisively the implementation of the investment projects co-financed by the European Union. Here are included the investment and operational costs, the delivery dates, the revenues' increase, the performance of the project's products ultimately, obtaining the benefits of the project through the project. If the previsions put at risk the economic part of the project, it's the investor's responsability to determine the needed changes and, ultimately, in worst case, to stop the project (Rodney J.T, Stephen J.S, 2004).

If the analysis is accurate, it helps choose the best project or it could lead to the decision to continue or to drop the project (Anthony E.B, David H.G., Aidan R.V., David L.W., 2001).

Please note that our study, through its conclusions, is a pioneer for it establishes for the first time in Romania, that renewable energy from solar sources, is not recommended for funding based on financial analysis but only on the basis of economic analysis.

The financial analysis of the PHOTOVOLTAIC PARK DUMBRAVENI was conducted according to the indicators and principles found in the documents below:

- The Applicant's Guide SOP PRIORITY AXIS 4 Increasing energy efficiency and security of supply in the context of combating climate change, AREA OF INTERVENTION 4.2 Valorisation of renewable energy resources for producing green energy, see OPERATION Supporting investments in upgrading and building new power and heating production capacities by valorisation of renewable energy resources: biomass, micro hydro (in units with an installed capacity lower or equal to 10MW), solar, wind, bio fuels and other renewable energy resources;

- Guidance on the methodology for carrying our Cost - Benefit Analysis, developed by the European Commission for the 2007 - 2013 programming period, coupled with the indications written in the Guide to cost - benefit analysis of investment projects, developed by the Evaluation Unit DG Regional Policy;

- Financial and Economic Analysis of Development Projects Manual (EcoFin Manual);

- $\quad$ SF Model - annex to Government Directive 28/2008

- Constant prices

\section{Research methodology}

The theoretical model that was used is the DCF model (Discounted Cash Flow), which quantifies the difference between revenues and expenditure generated by the project during its duration, adjusting this difference with a discount factor, an operation that is necessary to "bring" a future value into the present. In this method, the non-monetary flows, such as depreciation and provisions, are not taken into account.

The determining factors in choosing the optimum solution - for investment projects, and for our paper - are the financial rate of return and the net present value, which was determined below:

Net present value - is generally calculated with the formula: 


$$
N P V=\sum_{i=1}^{n} \frac{V_{i}-C_{i}-I_{i}}{(1+r)^{i}}+\frac{R V}{(1+r)^{i}}
$$

Where $\mathrm{r}=$ Updating rate $(5 \%)$

Io $=$ investment made over a period shorter than one year

$\mathrm{Ri}=$ operational revenue in year $\mathrm{i}$

$\mathrm{Ci}=$ operational cost in year $\mathrm{i}$

$\mathrm{RV}=$ residual value

$\mathrm{n}=$ the lifetime of the investment

$\mathrm{Ii}=$ investment made in year $\mathrm{i}$

The Internal Rate of Return (IRR) results from the equation that equals the net present value (NPV) to zero.

$$
\mathrm{NPV}=0
$$

In order to consider it feasible, an investment project must have an IRR level at least equal to the updating rate.

\section{Analysis of alternatives:}

\section{Option 0 or BAU - "business as usual"}

Option 0 is the assumption that the investment is not implemented. Considering the company was founded in December 2009 and hasn't run any activity until now - the present activity is null - the incremental result of the prognosis is similar with the result obtained as a project.

\section{Technical and economic alternatives}

There are several types of solar cells: mono-crystalline, polycrystalline, amorphous, thin layer, CIS (copper indium diselenide) and CdTe (cadmium telluride), CIGS, etc. The differences between these cells are the structure and the display of the atoms. This will also provide each solar cell with a specific look. But the biggest difference is made by efficiency. A cell's efficiency is measured by the percentage of light energy transformed into electricity. Mono-crystalline and polycrystalline solar cells have almost the same efficiency, being the largest multitude of solar cells existent on the market.

Depending on the crystalline nature of the semiconductor material used to obtain photovoltaic cells, there are three types of photovoltaic cells in accordance to which the alternatives of the project have been established:

- Mono-crystalline;

- Polycrystalline;

- Amorphous.

\section{Option 1 - Mono-crystalline solar panels}

Mono-crystals are obtained in the shape of baguettes or sticks by pouring pure silicon. These baguettes are subsequently cut into very thin lamellas that are used to manufacture photovoltaic cells. This technological process ensures a high level of efficiency for the photoelectric conversion, but is also the most expensive. They are made from a large area of silicon crystal. These types of solar panels are the most efficient in absorbing sunlight and in converting it into electricity, but they are the most expensive. Such a type of solar panel copes the best in conditions of low light when the other types of solar panel are less efficient. Panels made of mono-crystals have been largely used for over 20 years. They are usually used in applications of high reliability, such as telecommunications. 


\section{Option 2 - Polycrystalline solar panels}

Poly-crystals are obtained through a less expensive production process, consisting in pouring liquid silicon into blocks, which are subsequently cut into thin lamellas. Crystals of different sizes and shapes are formed during the solidification process and the brims of these crystals have some structural flaws. As a result of these flaws, the photovoltaic cells manufactured through this method are less efficient.

Polycrystalline is a frequent type of solar panels used today. They are slightly less efficient compared to mono-crystalline, but they are less expensive to manufacture. Instead of a large crystal area, this type of solar panel consists of several small areas of silicon crystals. An important detail is that this type of solar panel can function normally at different temperatures, without losing a lot of efficiency.

\section{Option 3 - Amorphous solar panels}

The amorphous structure is obtained by covering with an extremely thin silicon layer a glass surface or a substratum made of a different material. In this case, the solidification of atoms is not achieved in a crystalline structure, but as an atomic network with irregular display, named amorphous structure. This atomic network has numerous flaws that diminish the electric performances of the material. The thickness of the amorphous silicon layer obtained through this method is less than $1 \mu \mathrm{m}$. As a comparison, the thickness of a human hair is 50 to $100 \mu \mathrm{m}$. The manufacturing costs of the amorphous silicon are very low due to the extremely low quantities of used material, but the efficiency of the photovoltaic cells that use amorphous silicon is much lower than those using crystalline structures of material. Due to the low cost, the photovoltaic cells with amorphous silicon are mainly used to manufacture low power equipments, such as watches or pocket calculators. These are also used on sailing boats as well as other types of transports.

\section{The option recommended by the developer}

The table below presents the performances of the three types of photovoltaic cells in terms of converting solar energy into electricity.

Table no. 1

\begin{tabular}{|c|c|c|}
\hline \multicolumn{2}{|c|}{ The performances of different types of photovoltaic cells } \\
\hline Material & $\begin{array}{c}\text { Efficiency in } \\
\text { laboratory conditions }\end{array}$ & $\begin{array}{c}\text { Efficiency in conditions of mass } \\
\text { production }\end{array}$ \\
\hline $\begin{array}{c}\text { Mono-crystalline } \\
\text { silicon }\end{array}$ & $24 \%$ & $14 \ldots 17 \%$ \\
\hline $\begin{array}{c}\text { Polycrystalline } \\
\text { silicon }\end{array}$ & $18 \%$ & $13 \ldots 15 \%$ \\
\hline Amorphous silicon & $13 \%$ & $5 \ldots 7 \%$ \\
\hline
\end{tabular}

Source: „Parc fotovoltaic“ project, SC SOLAR ENERGY SRL

Mono-crystalline and polycrystalline solar cells have almost the same efficiency, being also the largest multitude of commercial solar cells existent on the market. As seen in the table above, the efficiency indicators for mass production for the two types of photovoltaic cells - monocrystalline and polycrystalline - have a range of identical values for both materials, $14-15 \%$.

Here are some of the phenomena that limit the efficiency growth for photovoltaic cells:

- A significant part of the photons that compose solar radiation have an insufficient energy level to cause the transition of the electrons from the valence layer to the conduction layer;

- The energy of photons with low energy level is turned into heat and not electricity;

- Optical losses occur on the surface of the photovoltaic cells due to the reflection of the solar radiation; 
- Other losses occur due to the electric resistance of the semiconductor material or of the connecting electrical cables;

- The structure flaws of the photovoltaic cell's materials worsen their performances.

The next table presents the theoretical maximum efficiencies of the photovoltaic conversion, which may be reached in optimum conditions for different types of semiconductor materials, along with the value of the "energy barrier", meaning the difference between the energy level of the conduction layer and of the valence layer.

Table no. 2

The theoretical maximum efficiencies of the photovoltaic conversion

\begin{tabular}{|c|c|c|c|}
\hline Indicators & $\begin{array}{l}\text { Polycrystalline } \\
\text { solar panels }\end{array}$ & $\begin{array}{c}\text { Mono- } \\
\text { crystalline solar } \\
\text { panels } \\
\end{array}$ & Conclusions \\
\hline Total panels & 10.902 & 10.902 & $\begin{array}{l}\text { The hypothesis to make the } \\
\text { investment with the same number of } \\
\text { panels and the same panel } \\
\text { dimensions is maintained }\end{array}$ \\
\hline Watt power / panel & 230 & 200 & $\begin{array}{l}\text { By keeping the dimensions of the } \\
\text { panels, the installed power of the } \\
\text { mono-crystalline panels is lower } \\
\text { than for polycrystalline panels }\end{array}$ \\
\hline Installed kw power & $2.515,39$ & 2.180 & $\begin{array}{l}\text { For the same number of panels and } \\
\text { the same size, the installed power is } \\
\text { lower for mono-crystalline panels }\end{array}$ \\
\hline $\begin{array}{l}\text { Cost Euro / installed } \\
\text { kw }\end{array}$ & 2.790 & 3.130 & $\begin{array}{l}\text { Higher installation costs by } 5 \% \text { for } \\
\text { mono-crystalline panels }\end{array}$ \\
\hline $\begin{array}{l}\text { Required panels for } \\
\text { power equalization }\end{array}$ & 10.902 & 12.537 & $\begin{array}{l}\text { By using mono-crystalline panels, } \\
\text { in order to maintain the level of } \\
\text { installed power are necessary } 1635 \\
\text { more panels than in the case of } \\
\text { polycrystalline panels, which } \\
\text { increases the surface of the area } \\
\text { needed for the investment, as well } \\
\text { as the implementation costs }\end{array}$ \\
\hline Efficiency & $12,60 \%$ & $14,60 \%$ & $\begin{array}{l}\text { Mono-crystalline panels have an } \\
\text { operating efficiency higher by } 2 \% \\
\text { than the polycrystalline panels }\end{array}$ \\
\hline $\begin{array}{l}\text { Released energy } \\
\text { kWh }\end{array}$ & 3.797 .285 & 3.368 .027 & \\
\hline $\begin{array}{l}\text { Investment value - } \\
\text { Euro without VAT }\end{array}$ & 8.199 .142 & 8.030 .833 & $\begin{array}{l}\text { The investment value is lower for } \\
\text { mono-crystalline panels because the } \\
\text { installed power is lower. Although } \\
\text { the cost euro/ installed kw is higher } \\
\text { for mono-crystalline panels, the } \\
\text { investment value drops because } \\
\text { these types of panels are totalling a } \\
\text { lower installed power for the land } \\
\text { area associated to the project }\end{array}$ \\
\hline
\end{tabular}

Source: „Parc fotovoltaic“ project, SC SOLAR ENERGY SRL

Given the presented conditions, the developer recommends as the best choice to achieve the investment the development of a new electricity production capacity by using solar panels with polycrystalline photovoltaic cells. 


\section{Financial analysis}

The financial analysis aims to capture the global impact of the project by estimating the reductions recorded for various chapters of costs and revenue surplus. General viewpoints:

- The used financial analysis method is the consolidated analysis (we see the beneficiary of the investment and the owner of the infrastructure as the same entity - SC SOLAR ENERGY SRL);

- The used method was the discounted cash flow;

- The operating and maintenance revenues and costs (operating costs) were determined for the activity of the company run as a project;

- Depreciation and provisions were not take into account;

- The financial projection was done for a span of 15 years;

- $\quad$ The used discount rate was 5\%;

- Values were expressed in RON

\section{Option 1 - Mono-crystalline solar panels}

The financial performance of the project ${ }^{3}$

Table no. 3

\begin{tabular}{|c|c|c|}
\hline \\
\hline Project indicator & Resulted value & Conclusion \\
\hline \multicolumn{3}{|r|}{ INVESTMENT } \\
\hline $\begin{array}{l}\text { Internal rate of } \\
\text { return }(\mathrm{FIRR} / \mathrm{C})\end{array}$ & $1,54 \%$ & $\begin{array}{l}\mathbf{0}<\operatorname{IRR}(\mathbf{C})<\mathbf{1 3 \%}-\text { the project is not financially } \\
\text { profitable (it requires financial assistance from SOP) }\end{array}$ \\
\hline $\begin{array}{l}\text { Net present value } \\
\text { (FNPV/C) }\end{array}$ & -8.282 .659 & $\begin{array}{l}<0 \text { (negative value) }- \text { the net revenues are not able to } \\
\text { cover the investment costs (the project requires financial } \\
\text { assistance from SOP) }\end{array}$ \\
\hline $\begin{array}{l}\text { The benefit - cost } \\
\text { ratio }\end{array}$ & 4,28 & $\begin{array}{l}>1 \text { (improper value) - the net revenues are able to cover } \\
\text { investment costs but not the financial costs (the project } \\
\text { requires financial assistance from SOP) }\end{array}$ \\
\hline $\mathrm{PP}$ & 15,56 & Payback period \\
\hline EPC & 1.795,53 lei/mwh & Energy production cost \\
\hline \multicolumn{3}{|c|}{$\begin{array}{l}\text { FINANCIAL SUSTAINABILITY } \\
\end{array}$} \\
\hline $\begin{array}{l}\text { Total cumulative } \\
\text { cash flow }\end{array}$ & Positive & The project is financially self-sustainable \\
\hline \multicolumn{3}{|c|}{$\begin{array}{l}\text { In conclusion, the results of the financial analysis revels the projects needs co-financing from } \\
\text { European Funds because the financial net present value of the investment (FNPV/C) minus the } \\
\text { contribution from the Funds is negative. }\end{array}$} \\
\hline
\end{tabular}

Source: „Parc fotovoltaic“ project, SC SOLAR ENERGY SRL

\footnotetext{
${ }^{3}$ The financial indicators of the project were calculated by using Word Excel, IRR and NPV functions, according to annex no. 1
} 
Option 2 - Polycrystalline solar panels

Table no. 4

The financial performance of the project

\begin{tabular}{|c|c|c|}
\hline Project indicator & Resulted value & Conclusion \\
\hline \multicolumn{3}{|r|}{ INVESTMENT } \\
\hline $\begin{array}{l}\text { Internal rate of } \\
\text { return }(\text { FIRR/C) }\end{array}$ & $1,92 \%$ & $\begin{array}{l}\mathbf{0}<\operatorname{IRR}(\mathbf{C})<\mathbf{1 3 \%}-\text { the project is not financially } \\
\text { profitable (it requires financial assistance from SOP) }\end{array}$ \\
\hline $\begin{array}{l}\text { Net present value } \\
(\text { FNPV/C) }\end{array}$ & -7.520 .876 & $\begin{array}{l}<0 \text { (negative value) }- \text { the net revenues are not able to } \\
\text { cover the investment costs (the project requires financial } \\
\text { assistance from SOP) }\end{array}$ \\
\hline $\begin{array}{l}\text { The benefit - cost } \\
\text { ratio }\end{array}$ & 4,82 & $\begin{array}{l}>1 \text { (improper value) - the net revenues are able to cover } \\
\text { investment costs but not the financial costs (the project } \\
\text { requires financial assistance from SOP) }\end{array}$ \\
\hline PP & 14,88 & Payback period \\
\hline EPC & $\begin{array}{l}1.832,28 \\
\text { lei/mwh }\end{array}$ & Energy production cost \\
\hline \multicolumn{3}{|c|}{$\begin{array}{l}\text { FINANCIAL SUSTAINABILITY } \\
\end{array}$} \\
\hline $\begin{array}{l}\text { Total cumulative } \\
\text { cash flow }\end{array}$ & Positive & The project is financially self-sustainable \\
\hline
\end{tabular}

Source: „Parc fotovoltaic“ project, SC SOLAR ENERGY SRL

\section{Economic analysis}

Given the magnitude of the economic and social impact of the electricity production projects, the results of the financial analysis are significant only insofar they are supported and completed by the results of the socio-economic analysis. Typically, infrastructure projects have a financial rate of return lower than the discount rate. Given the fact these projects have extremely high investment costs, they can't be financed through classic methods, such as bank loans. The stated goal of infrastructure projects is the economic and social welfare of the region, which may be measured only by using the performance indicators from the socio-economic analysis.

The reasoning of the socio-economic analysis is highlighted in the figure below:

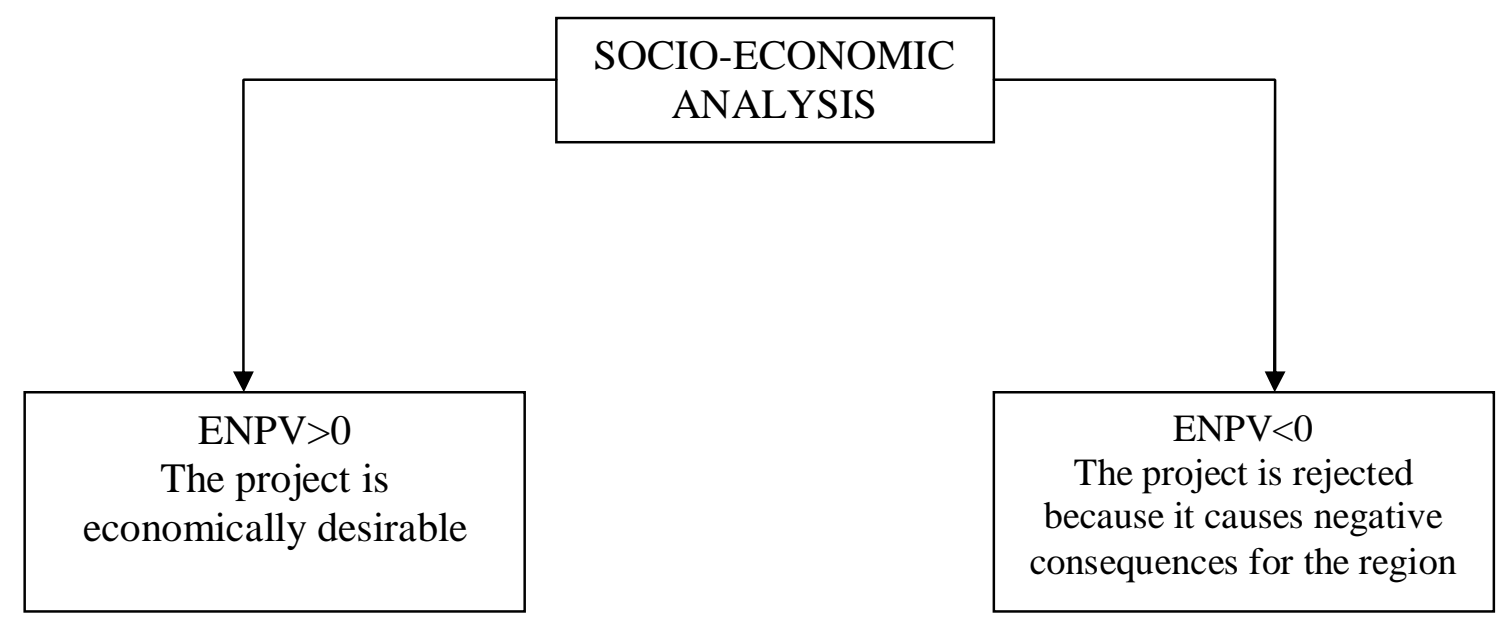

Figure no. 1 -The reasoning of the socio-economic analysis 


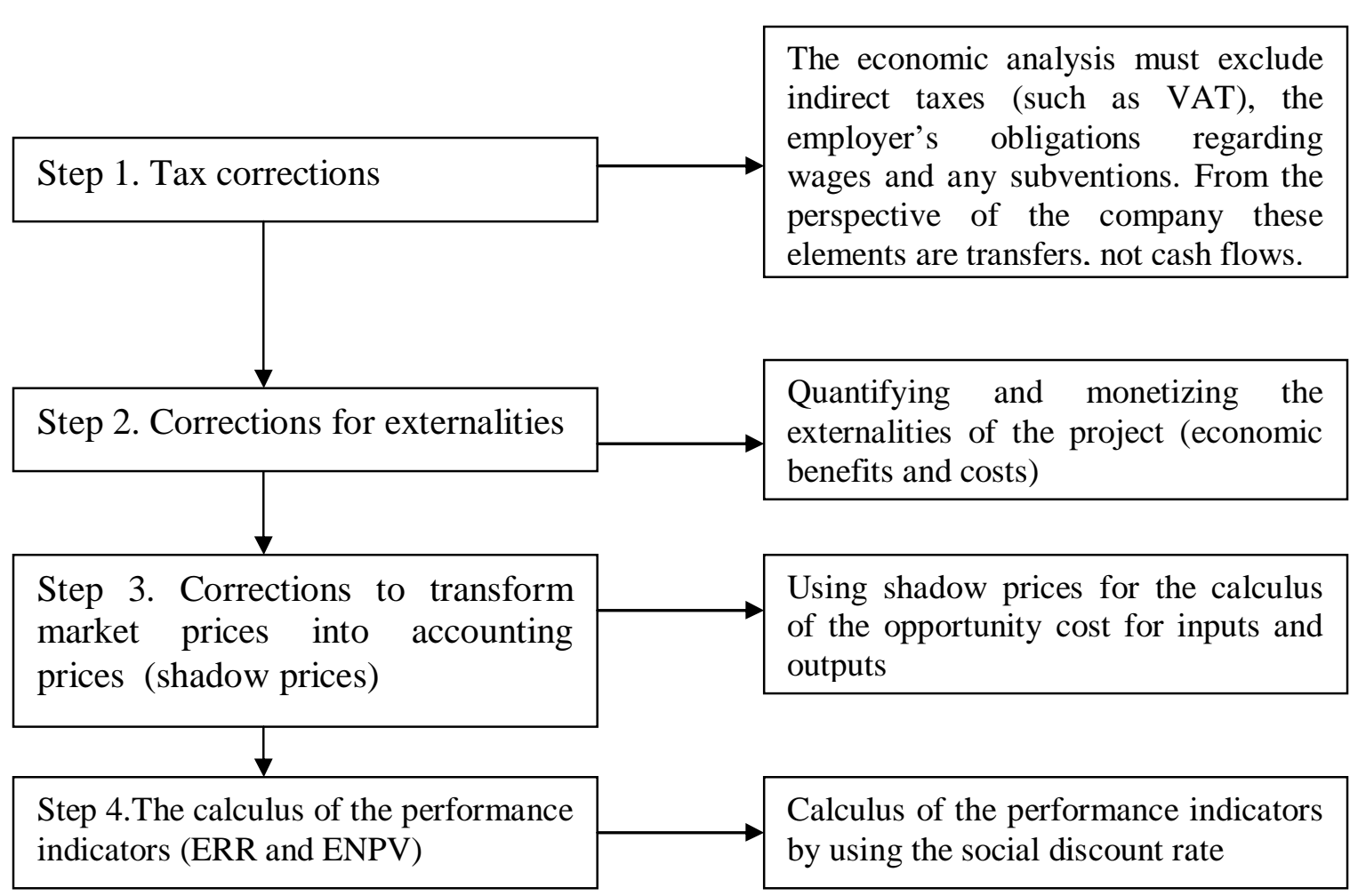

Figure no. 2 -The stages of the socio-economic analysis

The cost - benefit analysis tries to take into account all the costs and the benefits of the company as a whole. For this reason, some people refer to the cost - benefit analysis as a social cost - benefit analysis.

The cost - benefit analysis (CBA) is a method to assess a policy that quantifies in monetary terms the value of all the consequences of this policy over all the members of society. The net social beneficiary expressed the value of this policy. The difference between the social benefits (B) and social costs $(\mathrm{C})$ is the net social benefit (NSB):

$$
\mathrm{NSB}=\mathrm{B}-\mathrm{C}
$$

More specifically, the net social benefit (NSB) achieved as a result of public policy is equal to:

$$
\mathrm{NSB}=\Delta \mathrm{CS}+\Delta \mathrm{PS}+\Delta \mathrm{GR}
$$

Where $\Delta \mathrm{CS}, \Delta \mathrm{PS}, \Delta \mathrm{GR}$ represent total variations in the earnings of consumers, producers and budgetary income that result after implementing the policy.

CBA is applicable to policies, programmes, projects, regulations, experiments and other governmental interventions. The main purpose of CBA is to help in taking social decisions.

In conclusion, starting from the results generated by the monetary inputs, the following levels for the synthetic basic indicators of the socio-economic analysis resulted: 
Table no. 5

\begin{tabular}{|l|c|l|}
\hline \multicolumn{1}{|c|}{ Project indicator } & Resulted value & \multicolumn{1}{c|}{ Conclusion } \\
\hline $\begin{array}{l}\text { Internal rate of return } \\
\text { (IRR) }\end{array}$ & $\mathbf{1 1 , 2 8}$ & $\begin{array}{l}>\text { 5,5\% (social discount rate-> The project is } \\
\text { Opportune in terms of economic and social aspects } \\
\text { (economic - social benefits) }\end{array}$ \\
\hline $\begin{array}{l}\text { Economic net present } \\
\text { value (ENPV) }\end{array}$ & $\mathbf{1 3 . 6 4 1 . 7 7 7}$ & $\begin{array}{l}>\text { O (positive value) society needs the project } \\
\text { because of the benefits brought to the economy } \\
\text { (the project DESERVES financial aid from ERDF) }\end{array}$ \\
\hline $\begin{array}{l}\text { The benefit - cost } \\
\text { ratio (Rb/c_E) }\end{array}$ & $\begin{array}{l}>\mathbf{1} \text { (improper value) -> total benefits exceed the } \\
\text { costs of the project (the project DESERVES } \\
\text { financial aid from ERDF) }\end{array}$ \\
\hline
\end{tabular}

The cost - benefit analysis is a method used in European evaluations, upon which the decisions to finance investments are made. The method for indicators calculation above, using Parc fotovoltaic SC SOLAR ENERGY SRL informations as data source is synthetically presented in the appendix.

\section{Conclusions}

Renewable energy from solar sources is not recommended for funding based on financial analysis but only on the basis of economic analysis in Romania.

\section{References}

1. Achim M.I.., Hada, T., 2007. Managementul si Finantarea Afacerilor, Risoprint Publishing House, Cluj Napoca.

2. Bisa, C. coord., 2005. Elaborarea Studiilor de Fezabilitate si a Planurilor de Afaceri, BMT Publishing House Bucharest.

3. Boardman, A. E., Greenberg, D. A., Vining, A. R., Weimer, D. L., 2004. Analiza CostBeneficiu concepte si practica-Second Edition, ARC Publishing House.

4. Boardman, A. E., Greenberg, D. A., Vining, A. R., Weimer, D. L., 2001. Analiza cost beneficiu. Concepte si practică, Arc Publishing House, Chisinău.

5. Helfert E.A., 2006. Tehnici de analiza financiara - ghid pentru crearea valorii, BMT Publishing House, Bucureşti

6. Huru, D., 2007. Investitiile, capital \& dezvoltare, Economica Publishing House Bucharest.

7. Guide to Cost-Benefit Analysis of Investment Projects - European regional Development Fund, Cohesion Fund and ISPA

8. Rodney, J.T, Stephen J.S, 2004. Manual Gower de management de proiect, Codecs Publishing House,. 


\section{Annex 1a. Calculus of the Financial rate of return for the investment}

\section{In thousand euros}

\begin{tabular}{|c|c|c|c|c|c|c|c|c|c|c|c|c|c|c|c|}
\hline & $\begin{array}{l}\text { Years } \\
2010\end{array}$ & 2011 & 2012 & 2013 & 2014 & 2015 & 2016 & 2017 & 2018 & 2019 & 2020 & 2021 & 2022 & 2023 & 2024 \\
\hline Sales & 0 & 0 & 0 & 514.840 & 1.716 .132 & 1.716 .132 & 1.716 .132 & 1.716 .132 & 1.716 .132 & 1.716 .132 & 1.716 .132 & 1.716 .132 & 1.716 .132 & 1.716 .132 & 1.716 .132 \\
\hline Total revenues & 0 & 0 & 0 & 514.840 & 1.716 .132 & 1.716 .132 & 1.716 .132 & 1.716.132 & 1.716.132 & 1.716 .132 & 1.716.132 & 1.716 .132 & 1.716 .132 & 1.716 .132 & 1.716.132 \\
\hline $\begin{array}{l}\text { Total operating } \\
\text { costs }\end{array}$ & 0 & 0 & 0 & 61.641 & 197.070 & 197.070 & 197.070 & 197.070 & 197.070 & 197.070 & 197.070 & 197.070 & 197.070 & 197.070 & 197.070 \\
\hline Pension allowances & 0 & 0 & 0 & 0 & 0 & 0 & 0 & 0 & 0 & 0 & 0 & 0 & 0 & 0 & 0 \\
\hline $\begin{array}{l}\text { Total investment } \\
\text { costs }\end{array}$ & 74.540 & 16.836 .860 & 14.662 .266 & 1.809 .141 & 0 & 0 & 0 & 0 & 0 & 0 & 0 & 0 & 0 & 0 & -23.330 .099 \\
\hline Total expenditure & 74.540 & 16.836 .860 & 14.662 .266 & 1.870 .782 & 197.070 & 197.070 & 197.070 & 197.070 & 197.070 & 197.070 & 197.070 & 197.070 & 197.070 & 197.070 & -23.133 .029 \\
\hline Net cash flow & -74.540 & $\begin{array}{r}16.836 .860 \\
\end{array}$ & 14.662.266 & -1.355 .943 & 1.519 .061 & 1.519 .061 & 1.519 .061 & 1.519.061 & 1.519.061 & 1.519 .061 & 1.519 .061 & 1.519 .061 & 1.519 .061 & 1.519 .061 & 24.849 .161 \\
\hline $\begin{array}{l}\text { Internal rate of } \\
\text { return for the } \\
\text { investment } \\
(\text { IRR/C) }\end{array}$ & $1,92 \%$ & & & & & & & & & & & & & & \\
\hline $\begin{array}{l}\text { Net present value } \\
\text { for the investment } \\
\text { (FNPV/C) }\end{array}$ & -7.5 & 0.876 & & & & & & & & & & & & & \\
\hline
\end{tabular}

Note: discount rate for NPV $=5 \%$ 


\section{Annex $1 \mathrm{~b}$. Calculation of the Financial rate of return for the investment - thousand euros}

\begin{tabular}{|c|c|c|c|c|c|c|c|c|c|c|c|c|c|c|c|c|}
\hline & & Years & & & & & & & & & & & & & & \\
\hline & $\mathrm{CF}$ & 2010 & 2011 & 2012 & 2013 & 2014 & 2015 & 2016 & 2017 & 2018 & 2019 & 2020 & 2021 & 2022 & 2023 & 2024 \\
\hline Tax correction & 1 & & & & & & & & & & & & & & & \\
\hline $\mathrm{CO} 2$ emissions & & & & & 176.488 & 176.488 & 176.488 & 176.488 & 176.488 & 176.488 & 176.488 & 176.488 & 176.488 & 176.488 & 176.488 & 176.488 \\
\hline $\begin{array}{l}\begin{array}{l}\text { Savings for } \\
\text { fossil } \\
\text { consumption } \\
\text { couel }\end{array} \\
\end{array}$ & & & & & 570.000 & 570.000 & 570.000 & 570.000 & 570.000 & 570.000 & 570.000 & 570.000 & 570.000 & 570.000 & 570.000 & 570.000 \\
\hline $\begin{array}{l}\text { Additional taxes to } \\
\text { the budget }\end{array}$ & & & & & 466.601 & 467.587 & 468.617 & 469.646 & 471.739 & 472.768 & 473.798 & 474.827 & 550.559 & 551.589 & 584.634 & 46.019 \\
\hline $\begin{array}{l}\text { Value growth train } \\
\text { location }\end{array}$ & & & & & 1.630 .636 & 1.630 .636 & 1.630 .636 & 1.630 .636 & 1.630 .636 & 1.630 .636 & 1.630 .636 & 1.630 .636 & 1.630 .636 & 1.630 .636 & 1.630 .636 & 1.630 .636 \\
\hline $\begin{array}{ll}\begin{array}{l}\text { Total } \\
\text { benefit }\end{array} & \text { external } \\
\end{array}$ & & 0 & $\mathbf{0}$ & $\mathbf{0}$ & 2.843 .725 & 2.844 .711 & 2.845 .741 & 2.846 .770 & 2.848 .863 & 2.849 .892 & 2.850 .921 & 2.851 .951 & 2.927 .683 & 2.928 .713 & 2.961 .757 & 2.423.142 \\
\hline Sales & 1 & 0 & 0 & 0 & 514.840 & 1.716 .132 & 1.716 .132 & 1.716 .132 & 1.716 .132 & 1.716 .132 & 1.716 .132 & 1.716 .132 & 1.716 .132 & 1.716 .132 & 1.716 .132 & 1.716 .132 \\
\hline Total revenue & & 0 & 0 & 0 & 3.358 .564 & 4.560 .843 & 4.561.872 & 4.562 .902 & 4.564.994 & 4.566 .024 & 4.567.053 & 4.568.082 & 4.643.815 & 4.644.844 & 4.677.889 & 4.139.274 \\
\hline $\begin{array}{l}\text { Quantifiable socio- } \\
\text { economic costs }\end{array}$ & & & & & & & & & & & & & & & & \\
\hline $\begin{array}{l}\text { Total } \\
\text { costs }\end{array}$ & & 0 & $\mathbf{0}$ & 0 & 0 & 0 & 0 & 0 & $\mathbf{0}$ & 0 & 0 & $\mathbf{0}$ & $\mathbf{0}$ & $\mathbf{0}$ & 0 & 0 \\
\hline $\begin{array}{ll}\begin{array}{l}\text { Total } \\
\text { costs }\end{array} & \text { operating } \\
\end{array}$ & 0,791 & 0 & 0 & 0 & 48.758 & 155.883 & 155.883 & 155.883 & 155.883 & 155.883 & 155.883 & 155.883 & 155.883 & 155.883 & 155.883 & 155.883 \\
\hline $\begin{array}{l}\text { Lowering } \\
\text { hospitalisation costs }\end{array}$ & 1 & & & & & & & & & & & & & & & \\
\hline $\begin{array}{ll}\begin{array}{l}\text { Total } \\
\text { costs }\end{array} & \text { investment } \\
\end{array}$ & 0,9507 & 70.866 & 16.006 .803 & 13.939 .416 & 1.719 .950 & 0 & 0 & 0 & 0 & 0 & 0 & 0 & 0 & 0 & 0 & -22.179 .925 \\
\hline Total expenditure & & 70.866 & 16.006 .803 & 13.939.416 & 1.768 .708 & 155.883 & 155.883 & 155.883 & 155.883 & 155.883 & 155.883 & 155.883 & 155.883 & 155.883 & 155.883 & -22.024 .043 \\
\hline Net cash flow & & -70.866 & -16.006 .803 & -13.939 .416 & 1.589 .856 & 4.404 .960 & 4.405.990 & 4.407.019 & 4.409 .112 & 4.410 .141 & 4.411.170 & 4.412 .200 & 4.487.932 & 4.488.962 & 4.522.006 & 26.163.317 \\
\hline $\begin{array}{l}\text { Internal rate of } \\
\text { return for the } \\
\text { investment } \\
\text { (IRR/C) }\end{array}$ & & $11,28 \%$ & & & & & & & & & & & & & & \\
\hline $\begin{array}{l}\text { Net present value } \\
\text { for the investment } \\
\text { (FNPV/C) }\end{array}$ & & & 13.641 .77 & & & & & & & & & & & & & \\
\hline
\end{tabular}

Note: discount rate for NPV $=5,5 \%$ 